University of Nebraska - Lincoln

DigitalCommons@University of Nebraska - Lincoln

Faculty Publications from the Harold W. Manter Laboratory of Parasitology

1950

Studies on Some North American Shrew Cestodes

Robert L. Rausch

University of Washington, rausch@u.washington.edu

Follow this and additional works at: https://digitalcommons.unl.edu/parasitologyfacpubs

Part of the Parasitology Commons

Rausch, Robert L., "Studies on Some North American Shrew Cestodes" (1950). Faculty Publications from the Harold W. Manter Laboratory of Parasitology. 564.

https://digitalcommons.unl.edu/parasitologyfacpubs/564

This Article is brought to you for free and open access by the Parasitology, Harold W. Manter Laboratory of at DigitalCommons@University of Nebraska - Lincoln. It has been accepted for inclusion in Faculty Publications from the Harold W. Manter Laboratory of Parasitology by an authorized administrator of DigitalCommons@University of Nebraska - Lincoln. 
Rausch \& Kuns in Journal of Parasitology (October 1950) 36(5).

Copyright 1950, American Society of Parasitologists. Used by permission.

\title{
STUDIES ON SOME NORTH AMERICAN SHREW CESTODES
}

\author{
Robert Rausch and Merle L. Kuns
}

U. S. Public Health Service, Anchorage, Alaska, and

Department of Biological Sciences, Purdue University, Lafayette, Indiana.

In spite of the importance of the various species of shrews to the biotic community, several aspects of their ecology remain very incompletely known. The helminths parasitic in the more conspicuous small mammals in North America have been studied more or less completely, but those occurring in shrews have been largely disregarded. This situation is particularly inappropriate when one considers that shrews often constitute the most abundant mammalian group in a given area. We have attempted to secure an adequate amount of shrew helminth material for study, and it is the purpose of this paper to present observations resulting from this work.

There have been, apparently, three species of cestodes recorded so far from North American shrews; these are Hymenolepis anthocephalus Van Gundy, 1935, Diorchis reynoldsi Jones, 1944, and Protogynella blarinae Jones, 1943. These parasites have been reported from the short-tailed shrew, Blarina brevicauda Say sspp. It seems that the parasites of the smaller shrews have been entirely neglected. This in part may be due to the difficulty with which good shrew material is obtained, since the animals undergo extremely rapid decomposition after death, often making cestodes useless for study. Taxonomic difficulties with the host animals themselves also may be considerable, particularly where several species occur in the same region.

For several years the senior author has collected helminths from shrews, but in some cases good material has been obtained only after repeated attempts. Most of the shrew material with which we are concerned was collected in the Central States. During the summer of 1948 the writers collected helminths from a number of shrews in the Jackson Hole region of Wyoming. Additional material has been obtained from the western provinces of Canada and from Alaska. Material was secured from the following species of shrews: Blarina brevicauda, Sorex cinereus, S. vagrans, S. obscurus, S. articus, and Microsorex hoyi. Subspecific names of the hosts are not considered here, except where mentioned in connection with a specific cestode. Most of the taxonomic work regarding the shrews, particularly the Alaskan forms, has been done by the senior author at the U. S. National Museum.

The cestodes which we have so far observed in shrews are considered separately. Of these, 4 species are described as new.

\section{Protogynella blarinae Jones, 1943}

(Figs. 1 and 2)

The genus Protogynella was erected by Jones (1943) for a very small cestode taken from Blarina brevicauda in Virginia. We collected this species from the same host in southern Wisconsin, although it was not found commonly there. While we are not able to either corroborate or refute certain of Jones' statements, it is evident that certain details were overlooked by him. Protogynella blarinae was described as having a "sac-like, unarmed" rostellum. Careful study of this cestode has revealed that the rostellum is actually armed with minute hooks. The number of hooks appears to be 46 , and their length is about $4.0 \mu$ (Figs. 1 and 2). This added knowledge regarding $P$. blarinae requires modification of the generic concept. Jones' failure to include

Received for publication, March 11, 1950. 


\section{THE JOURNAL OF PARASITOLOGY}

a drawing of an entire mature segment causes some difficulty in understanding the morphology of this species; it is possible that certain other characters have been incorrectly interpreted, but conclusive evidence must be derived from the study of material in unusually favorable condition.

\section{Diorchis reynoldsi Jones, 1944}

The cestode was recorded by Jones (1944) from Blarina brevicauda, taken in Virginia. We have never observed this cestode in Blarina, nor in any other shrew species. It appears to have a restricted distribution.

\section{Hymenolepis anthocephalus Van Gundy, 1935}

Hymenolepis anthocephalus was commonly observed in Blarina brevicauda in the states of Ohio, Michigan, and Wisconsin. It is the largest cestode so far found in North American shrews. Apparently this species is restricted in occurrence to Blarina, since we have never taken it from shrews of other genera, even though they were collected from the immediate locality where infected specimens of Blarina were common.

\section{Hymenolepis blarinae n. sp.}

(Figs. 3 and 4)

Diagnosis: Strobila usually about $90 \mathrm{~mm}$. long; greatest width, slightly over $1.0 \mathrm{~mm}$. attained in gravid segments. Margins of strobila serrate; segments, 350 to 430 in number, usually wider than long, with fully gravid segments nearly square. Scolex about $250 \mu$ in diameter; well developed and strongly set off from neck. Suckers about 125 by $190 \mu$. Rostellum not prominent; armed with 10 hooks, $33 \mu$ in length. Ventral excretory canals up to $56 \mu$ in diameter; dorsal canals, situated lateral to former, $5 \mu$ in diameter. Genital pores unilateral, dextral; situated near the middle of segment. Cirrus sac from 110 to $130 \mu$ long by about $16 \mu$ wide. Cirrus spinose. Testes in mature segments about $50 \mu$ in diameter; single anterior testis more or less between two posterior testes. Ovary elongate, with long axis transverse. Vagina posterior or ventral to cirrus sac. Vitelline gland posterior to ovary, near posterior margin of segment. Mature segments not observed posterior to first $1 / 4$ of length of strobila. Uterus first appears as transverse body in anterior part of segment; bilateral enlargements are formed, which enlarge until most of segment between excretory canals is filled by ovoid gravid uterus. Eggs apparently spherical, about $40 \mu$ in diameter; distortion resulting from fixation has prevented accurate measurement. Larval hooks $19 \mu$ long.

Host: Blarina b. brevicauda (Say).

Locality: Madison, Wisconsin.

Habitat: Small intestine.

Type: A slide bearing a complete specimen has been deposited in the Helminthological Collection of the U. S. National Museum, slide No. 47316.

Of other shrew cestodes belonging to the genus Hymenolepis, only one, H. scutigera (Dujar$\operatorname{din}, 1845)$, has 10 hooks which overlap in size those of the present species. These species, however, are readily differentiated on the basis of hook shape, in addition to other morphological characters.

\section{Hymenolepis parva n. sp.}

(Figs. 5 and 6)

Diagnosis: Strobila from 3 to $5 \mathrm{~mm}$ in length; greatest width, attained in gravid segments, about $300 \mu$. Margins of strobila not serrate. Segments from 125 to 150 in number. Scolex from 160 to $190 \mu$ in diameter, markedly set off from neck. Suckers about $130 \mu$ in diameter. Rostellum well developed; armed with 10 hooks 34 to $40 \mu$ long. Ventral excretory canals about $8 \mu$ in diameter. Genital pores unilateral, dextral; situated near middle of segment. Cirrus sac from 60 to $96 \mu$ long by 12 to $22 \mu$ wide. Cirrus spinose; about $25 \mu$ long when protruded. External seminal vesicle present; in majority of cases it turns back ventrally upon cirrus sac, but may continue straight; in latter case gives appearance of cirrus sac extending across $2 / 3$ of segment. Testes 25 to $35 \mu$ in diameter in mature segments; situated in straight line. Ovary somewhat elongate, transverse, situated near middle of segment. Vitelline gland posterior and aporad to ovary, near posterior margin of segment. Vagina posterior to cirrus sac; seminal receptacle not prominent. Uterus first appears as transverse body which gradually enlarges to fill entire gravid segment. Eggs spherical, from 20 to $25 \mu$ in diameter.

Host: Sorex c. cinereus Kerr. Also recorded from S. cinereus streatori Merriam (Anchorage, Alaska); S. vagrans monticola Merriam (Jackson Hole, Wyoming); S. o. obscurus Merriam (Tolugak Lake, arctic Alaska - lat. $68^{\circ} 24^{\prime}$ N., long. $151^{\circ} 26^{\prime}$ W.) ; S. obscurus alascensis Merriam (Juneau, Alaska). 
Locality: Madison, Wisconsin.

Habitat: Small intestine.

Type: A slide bearing whole-mounts of paratype material has been deposited in the Helminthological Collection of the U. S. National Museum, slide No. 47317.

Hymenolepis parva appears to resemble most closely H. scutigera (Dujardin, 1845), the only other species of soricid Hymenolepis having 10 hooks of overlapping size. These two cestodes also have similar hook shapes. These species, however, may be differentiated on the basis of egg size and other morphological characters. Baylis (1934) found H. toxometra Baer, 1932, to be identical with $H$. scutigera. According to Baylis, uterus shape (an arc) and the greatly elongated gravid segments to differentiate $H$. scutigera from all other shrew species; this also applies to $H$. parva.

\section{Hymenolepis schilleri $\mathrm{n} . \mathrm{sp}$.}

(Figs. 7 and 8 )

Diagnosis: Strobila length from 20 to $25 \mathrm{~mm}$; greatest width attained in terminal gravid segments, about $1.5 \mathrm{~mm}$. Margins of strobila slightly serrate. Segments, about 300 in number, very much wider than long through strobila. Scolex strongly developed, from 410 to $420 \mu$ in diameter. Suckers about 70 by $80 \mu$. Rostellum powerful; armed with 22 hooks 27 to $30 \mu$ in length. Excretory canals markedly undulating; dorsal canal, about $8 \mu$ in diameter, situated dorsal to proximal margin of ventral canal; latter 16 to $40 \mu$ in diameter. Genital pores unilateral, dextral; situated in anterior third of margin of segment. Cirrus sac from 110 to $140 \mu$ long by about $16 \mu$ wide. Cirrus aspinose. Testes arranged in triangle near center of segment; two testes on same level, with third posterior to and between them. Ovary elongate, transverse; situated near anterior margin of segment. Vagina posterior to cirrus sac; large seminal receptacle may extend nearly to midline of segment. Vitelline gland transversely elongate; situated posterior to and parallel with ovary, near center of segment. Uterus first seen as transverse, rosette-like sac which gradually enlarges to fill entire gravid segment. Eggs from 21 to $24 \mu$ in diameter.

Host : Sorex c. cinereus Kerr.

Locality: Madison, Wisconsin.

Habitat: Small intestine.

Type: A slide bearing paratype material has been deposited in the Helminthological collection of the U. S. National Museum, slide No. 47318.

Of other soricid cestodes of the genus Hymenolepis, H. spinulosa Cholodkowsky, 1912, $H$. magnarostellata Baer, 1931, H. pistillum (Dujardin, 1845), H. maclaudi Joyeux and Baer, 1928, $H$. macroscelidarum Baer, 1926, $H$. furcata (Stieda, 1862), and $H$. uncinata (Stieda, 1862) all have a hook number approximating that of $H$. schilleri. However, according to published descriptions, only $H$. magnarostellata, $H$. maclaudi, $H$. pistillum, and $H$. furcata actually overlap $H$. schilleri in hook number, Of these, only $H$. magnarostellata and $H$. furcata overlap in hook length. The latter two species as well as the others mentioned above are readily differentiated from the present species on the basis of hook shape, in addition to other morphological characters.

This cestode is named in honor of Mr. E. L. Schiller, who has been of aid in securing supporting material for this study.

\section{Hymenolepis falculata $\mathrm{n} . \mathrm{sp}$.}

(Figs. 9 and 10)

Diagnosis: Strobila from 30 to $40 \mathrm{~mm}$. long; greatest width, attained in gravid segments, about $700 \mu$. Margins of strobila slightly serrate; segments, from 220 to 270 in number, slightly wider than long to nearly square. Scolex relatively small; from 180 to $220 \mu$ in diameter; suckers about 50 by $75 \mu$. Rostellum well developed; armed with 12 hooks from 22 to $25 \mu$ in length. Ventral excretory canals 32 to $64 \mu$ in diameter; dorsal canals, situated directly dorsal to latter, about $8 \mu$ in diameter. Genital pores unilateral, dextral; situated in anterior half of margin of segment. Cirrus sac elongate from 130 to $150 \mu$ long by 16 to $24 \mu$ in diameter. Cirrus spinose; about $70 \mu$ long when protruded. Testes arranged in triangle; two situated antero-poral and one postero-aporal. Testes about $80 \mu$ in diameter in mature segments. Ovary somewhat ovoid, with incised posterior margin; situated near middle of segment. Vagina posterior to cirrus sac; seminal receptacle not prominent. Ovoid vitelline gland situated in notch at posterior margin of ovary. Early uterus appears as wreath-like band completely surrounding female reproductive organs; open center of uterus persists until well toward end of strobila, when it disappears and the uterus fills entire gravid segment. Eggs ovoid; about $36 \mu$ in length. Accurate measurement of eggs prevented by distortion resulting from fixation. 
Host : Sorex c. cinereus Kerr.

Locality: Madison, Wisconsin.

Habitat: Small intestine.

Type: A slide bearing paratype material has been deposited in the Helminthological collection, U. S. National Museum, slide No. 47319.

Only two species of soricid cestodes of the genus Hymenolepis having 12 hooks have been described; these are $H$. scalaris (Dujardin, 1845) and $H$. dodecantha Baer, 1925. The hooks of both of these exceed those of $H$. falculata in length, and both differ in hook shape. The wreath-like shape of the early uterus of the latter serves to distinguish it readily from related species.

\section{DISCUSSION}

In addition to the 4 species described in the present paper, there are apparently 25 species of Hymenolepis which parasitize various shrews. Of these, only one, H. anthocephalus Van Gundy, 1935, has been described or recorded from North American hosts. It would seem, from present knowledge, that cestodes in North American shrews are strictly North American species, with none of the Eurasian forms represented insofar as the genus Hymenolepis is concerned. This is in contrast to certain other mammalian groups (e.g. microtine rodents) where Eurasian species occur more or less commonly, particularly in arctic-alpine regions. One of us (R. R.) has at present a large number of preserved shrews from the coast of the Bering Sea and Nunivak Island, the examination of which may divulge further information in this connection. Further studies on shrew helminths will be presented at a later date.

A key to the cestodes recorded from North American shrews has been prepared, based mainly on hook characters.

\section{Key To Species Of Cestodes In North American Shrews}

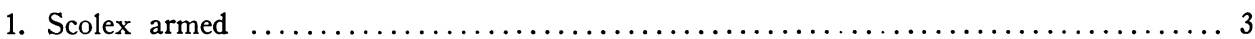

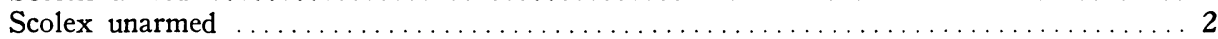

2. Scolex relatively large and globular; no rostellum .... H. anthocephalus Van Gundy, 1935

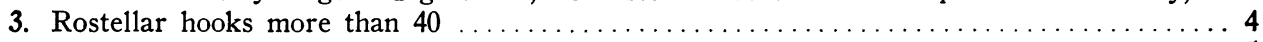

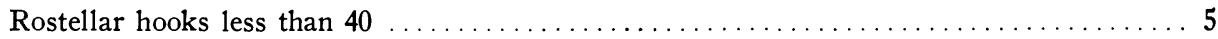

4. Strobila length about $1 \mathrm{~mm}$; about 46 minute hooks present

Protogynella blarinae Jones, 1944

Strobila length 7 to $10 \mathrm{~mm}$; about 100 minute hooks ........ Diorchis reynoldsi Jones, 1943

5. Rostellar hooks 22 in number; segments much wider than long ......... H. schilleri $\mathrm{n}$. sp. Rostellar hooks 12 in number; pre-gravid uterus wreath-like in appearance

H. falculata n. sp.

Rostellar hooks 10 in number

H........ 6

6. Strobila from 7 to $10 \mathrm{~mm}$. long; hook length 34 to $40 \mu$ long

Strobila about $90 \mu$ long; hook length $33 \mu$

H. blarinae n. sp.

\section{SUMMARY}

The cestodes of North American shrews are discussed, and 4 species, Hymenolepis blarinae, $H$. parva, $H$. schilleri, and $H$. falculata, are described as new. Rostellar hooks are reported for the first time from Protogynella blarinae Jones, 1944; this requires emendation of the generic diagnosis. Various host- and distribution records are also reported.

\section{REFERENCES}

Baylis, H. A. 1934 Miscellaneous notes on parasitic worms. Annals and Mag. Nat. History Ser. 10, 13: 223-228.

Jones, A. W. 1943 Protogynella blarinae n. g., n. sp., a new cestode from the shrew, Blarina brevicauda Say. Trans. Amer. Micr. Soc. 62: 169-173. 
Rausch \& Kuns in Journal of Parasitology (October 1950) 36(5).

Copyright 1950, American Society of Parasitologists. Used by permission.

Plate I
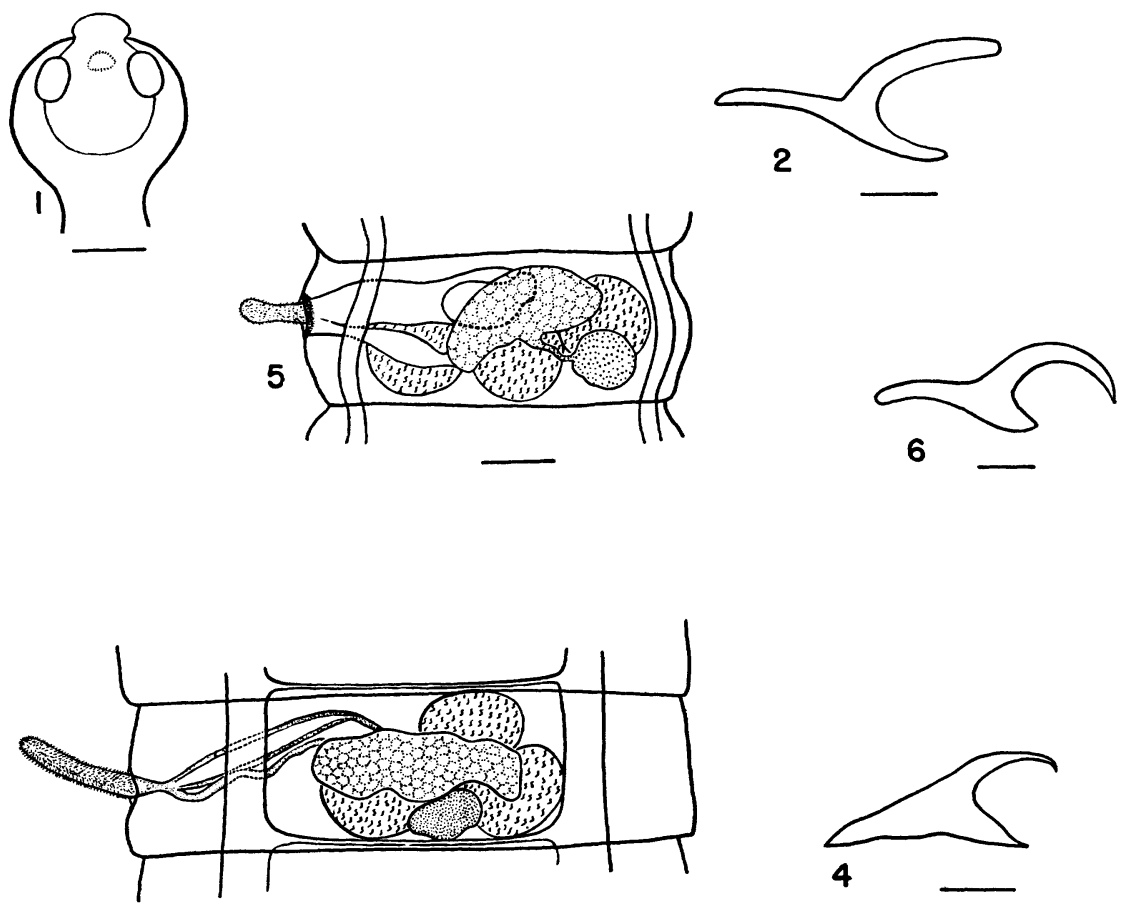

3
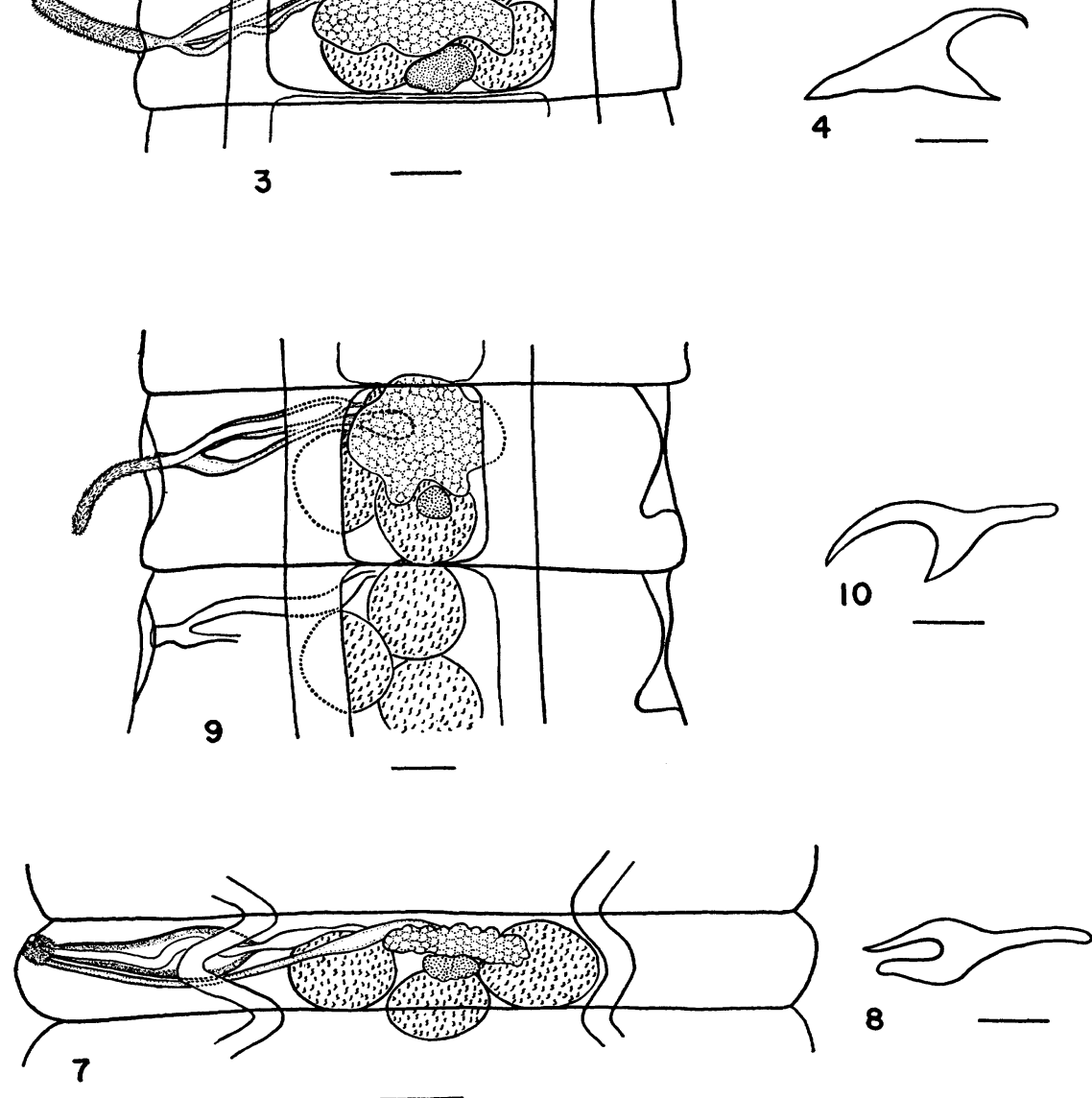
1944 Diorchis reynoldsi n. sp., a hymenolepidid cestode from the shrew. Trans. Amer. Micr. Soc. 63: 46-49.

VAN Gundy, C. O. 1935 Hymenolepis anthocephalus, a new tapeworm from the mole shrew, Blarina brevicauda Say. Trans. Amer. Micr. Soc. 54: 240-244.

\section{Explanation Of Plate}

Frg. 1. Scolex of Protogynella blarinae showing hooks on retracted rostellum. Scale has a value of $100 \mu$.

FIG. 2. Rostellar hook of $P$. blarinae. Scale has a value of $1 \mu$.

Fig. 3. Mature segment of Hymenolepis blarinae n. sp. Scale has a value of $40 \mu$.

Fig. 4 Rostellar hook of $H$. blarinae. Scale has a value of $10 \mu$.

FIg. 5. Mature segment of $H$. parva n. sp. Scale has a value of $20 \mu$.

Fig. 6. Rostellar hook of $H$. parva. Scale has a value of $9 \mu$.

FIG. 7. Mature segment of $H$. schilleri n. sp. Scale has a value of $60 \mu$.

FIg. 8. Rostellar hook of $H$. schilleri. Scale has a value of $10 \mu$.

Fig..9. Mature segment of $H$. falculata $n$. sp. Scale has a value of $80 \mu$.

Fig. 10. Rostellar hook of $H$. falculata. Scale has a value of $10 \mu$. 